\title{
The Analysis of Tragedy in Farewell My Concubine
}

\author{
Yifan Yang
}

\author{
Yunnan University \\ *Corresponding author.Email:743801157@qq.com
}

\begin{abstract}
The economic foundation determines the superstructure, and culture is the concentrated embodiment of economy and politics in a certain period of time. A specific historical period can often determine the fate of characters, and the tragedy produced under the powerlessness of the era can always make people pity and have compassion for it. Using the method of literature research, this dissertation will take the three protagonists in the film and Peking Opera, which is closely related to them, as the starting points to analyze how does the tragedies of both nobody and traditional Chinese culture come from in the great changing and turbulent era and what enlightenment does their tragedies have on modern people and society. The problem this article hopes to solve is how to correctly understand and inherit the Chinese traditional culture represented by Peking Opera, and how people should live with dignity and guard what values in the turbulent era.
\end{abstract}

Keywords: Tragic, Farewell My Concubine, Peking Opera, Turbulent era

\section{INTRODUCTION}

Tragedy is one of the main genres of drama, which mainly constitutes the basic content of the work based on the irreconcilable conflict between the protagonist and reality and its tragic ending. Its protagonists are mostly representatives of people's ideals and aspirations. Tragic aesthetics reveals the evils in life with a tragic ending, to arouse the sadness, anger and respect of the audience and achieve the purpose of improving ideology and sentiment. Since human history, countless joys, and sorrows, suffering and destruction of life have been closely connected with social life. Facing the death and suffering of individual life, audience will involuntarily touch the compassion and fear in our hearts [1]. Farewell My Concubine is one of the greatest films in Chinese film history, which focuses on the joys and sorrows of two

Peking Opera actors and a prostitute, Cheng Dieyi, Duan Xiaolou and Juxian, for half a century.

\section{TRAGEDY OF CHARACTERS- CHENG DIEYI}

"You can't live without being crazy. Indeed, you must be crazy when performing, but if we are also crazy in live, how can we live in this world and in this pile of mortals? " From the conversation with Duan Xiaolou, it was clearly to know Cheng Dieyi was deeply immersed in the world of Peking opera. He is a drama maniac, who lived in the play all his life and couldn't get out of the it. He did not even know which play his life should belong to.

\subsection{How was the gender barrier of Cheng Dieyi formed?}

Cheng Dieyi's tragedy stemmed from his gender disorder. Gender disorder means that children's behavioral understanding of their own gender is contrary to their true anatomical characteristics, such as male behavioral characteristics like women, or continuous denial that their body has male characteristics [2]. But he was not a transgender, because he always thought he was the concubine in the play and loved Duan Xiaolou, the overlord in the play. The film tells how Cheng Dieyi changed from a man to a woman, and how he moved step by step towards the "gender cognitive barrier", falling into the dilemma of "life is like a play, and play is like life". Through this gender cognitive impairment, he reached the peak of his life. It is also because of gender cognitive impairment that he could not complete his life values of "from the beginning to the end", and then went to self-destruction [3]. 


\subsubsection{Castration in Cheng's childhood time}

When Cheng Dieyi was a child, his mother, who was a prostitute, chopped off his sixth finger and sent him to the troupe. Six fingers, a piece of meat more than normal, which implied male genitalia. Only by cutting him off could he enters the troupe.

\subsubsection{Castration in Cheng's youth time}

Cheng Dieyi gradually grew up, and the masters of the troupe trained him as a female role. He always mispronounced his lines in Si Fan, a drama starring a female character, "I'm by nature a boy, not a girl." In his heart, he still felt that he is a boy. When Cheng Dieyi recited his lines again as "I'm by nature a boy, not a girl", Duan Xiaolou could not bear it. He took the pipe and stuffed it into Dieyi's lips, filling his mouth with blood. This "sexual act" was the second castration of Cheng Dieyi.

If the first two castrations were only spiritual, the eunuch's physical violence against him was an out and out physical castration. For the sake of Duan Xiaolou's future, he had no choice but to passively accept the insult. His male mind has been utterly damaged since then[4].

\subsection{How did his gender disorder cause his tragedy}

\subsubsection{Tragedy in Cheng's youth time: gender barriers prevent him from getting Duan's love}

In the 1930s, Cheng Dieyi's dream came true, who became a famous actor and was worshipped and pursued by the people in Beijing. The Peking Opera Farewell My Concubine, which he cooperated with Duan Xiaolou, also became the most popular at that time. Both in and out of the play, he always thought he was the Concubine. Cheng Dieyi loved Duan Xiaolou deeply, as much as the Concubine loved her overload in the play. They had promised to perform "from the beginning to the end". Dieyi thought that Xiaolou also loved him as much as the overlord loved his concubine in the play. But unfortunately, his overload Duan Xiaolou clearly distinguishes Peking Opera from reality. In his eyes, performing Peking Opera is just a means of making a living, and he does not love Cheng Dieyi at all. His marriage to the prostitute Juxian made Cheng Dieyi feel very hurt. Cheng Dieyi's overlord found another concubine, which exposed his fantasy of "from the beginning to the end" and made him perform very painful on the drama of life.

Cheng Dieyi's performance was appreciated by the local capitalist Yuan Shiqing. The director uses the technique of parallel montage to combine the wedding of Duan Xiaolou and Juxian with the cultivation of
Cheng Dieyi by Yuan Shiqing. When Dieyi found that Yuan Shiqing had Duan Xiaolou's favorite sword as a child and wanted to get him, Yuan Shiqing agreed but asked to rape Dieyi in exchange. What's more pathetic was that Duan Xiaolou did not care when he held the sword Cheng Dieyi obtained by selling his body. Dieyi's life was like the epitome of actors in that era, what he got in exchange for his beauty and excellent acting skills was only appreciated and played by the dignitary.

\subsubsection{Tragedy in Cheng's middle age}

Chinese society had changed dramatically after the anti - Japanese and liberation wars. The spiritual world of Cheng Dieyi was collapsed by the departure of Duan Xiaolou. He was increasingly addicted, and took apathetic hide in his own world, reluctant to face reality. The 1950s saw the gradual transformation into a communist society, and the role of Communist Party brought another social transformation to China. Cheng Dieyi worked hard to get rid of his addiction to smoking and began a new life but found that the world no longer belonged to him. Peking Opera in this era was no longer art. People did not pay attention to the beauty in the play, or the sweat actors pay. Instead, they only care about the position and the class. In addition to Dieyi, who was still immersed in his own world, everyone knew that the world has changed. No one dared to be a mantis. Only Dieyi, which represented the purity of traditional art, was forced by the red guards to be betrayed by everyone and left his stage forever.

In the 1960s, the wave of the Cultural Revolution swept across the country, pointing at Peking Opera, which was seen as an important part in the feudal culture. Cheng Dieyi and Duan Xiaolou were also suppressed by the red guards. First, Dieyi performed for the capitalists and landlords, then he performed for the Japanese, and then he took drugs. Finally, Duan Xiaolou pointed to Cheng Dieyi's deepest secret: his shameful relationship with Yuan Shiqing. At this moment, Cheng Dieyi's inner world completely collapsed. When Duan Xiaolou threw Cheng Dieyi's sword into the fire, which was gained by selling Dieyi's body for him, Cheng Dieyi finally understood that his beloved overlord was a complete coward and villain. "I haven't been a good man for a long time, but you, the overlord of Chu, knelt down and surrendered. How can the Peking Opera survive?" He thought Duan Xiaolou was the truest, the most heroic, the most aboveboard and the only person who could be entrusted. He said that Duan Xiaolou's promise to perform Peking Opera with him all his life was a lie, and what master said the value "from beginning to end" was a lie, Yuan Shiqing also lied to him when he said that "Peking Opera is the essence of Sinology". 


\subsubsection{Tragedy in Cheng's old age: gender barrier leaded Cheng to extinction}

In the late 1970s, after the Cultural Revolution, Cheng Dieyi and Duan Xiaolou got the opportunity to cooperate again. On the stage, Cheng Dieyi mispronounced the lines of Si Fan again: "I'm by nature a boy, not a girl" Duan Xiaolou smiled and said that he was wrong again, but Cheng Dieyi knew that he was not only wrong in his lines, but also wrong in his whole life. To make the illusion of the play come true, he must really die once and bury himself for the play and love. He took the overlord' s sword and ended his life, just as the Concubine in the same play died for the overlord, just as his master said: from the beginning to the end[5].

\section{TRAGEDY OF CHARACTERS- JUXIAN}

"Juxian is actually the real Concubine", said by Leslie Cheung, the actor who played the role of Cheng Dieyi. If Cheng Dieyi lived in the play and was the real Concubine in the play, then Juxian lived in reality and was the real Concubine in her whole life. Her personalities are complicated with too many characteristics: prostitute, naughty, smart, strong, dare to love and hate. But she was also a simple person, her wish was very simple: to be a normal person and always be with Duan Xiaolou. This woman who came out of the brothel used her life to pursue love and protect Duan Xiaolou, her overlord, and her tragedy also comes from this. When Duan Xiaolou betrayed her like what he did to Cheng Dieyi, she had no choice but to die like Concubine in the play.

In the brothel, when Duan Xiaolou tried to save Juxian by drinking the wedding wine with her who was humiliated by her clients, her eyes showed firm mercerization. When she heard Duan Xiaolou on stage playing Chu's song, she determined to rebel against the secular world and spend all of her money on being a regular person rather than a low-status prostitute. At the wedding, she lifted her veil, kicked off the red carpet and ran to Duan Xiaolou happily, she was also imagining that she could live a peaceful life with Duan Xiaolou and have their own child.

She also wanted to be with Duan Xiaolou from the beginning to the end. For her, Cheng Dieyi was not only her rival in love, but also a stumbling block that hinders her and Duan Xiaolou's happy life, because as long as Duan Xiaolou and Cheng Dieyi perform Peking opera together, he would always get into trouble. As she said of Cheng Dieyi, "I don't know whether this world is at odds with him, or he is at odds with this world." In this turbulent era, little people seem to be unable to live safely. Juxian's dream of living a peaceful life with Duan Xiaolou and having a child is dashed. Duan Xiaolou was the only one left.
Juxian believed that Cheng Dieyi caused her and Duan Xiaolou to be unable to live a happy life, while Cheng Dieyi also believed that Duan Xiaolou betrayed Peking Opera and his identity changed from the overlord to a coward because of Juxian. However, they are all wrong, because Duan Xiaolou's fall was not because of Cheng Dieyi or Juxian, but because of this turbulent era. Juxian wanted to be a good person, but to save Duan Xiaolou, she could make a promise to Dieyi that she would return to the brothel; Dieyi hated the Japanese and did not like Yuan Shiqing, but for Duan Xiaolou, he was willing to perform to the Japanese and be humiliated by Yuan Shiqing. It was precisely because of this that Dieyi dared to criticize modern drama when almost everyone supported modern drama. In the criticism of the Cultural Revolution, Juxian who were always afraid of getting into trouble would fight to protect Duan Xiaolou and defend the sword.

All kinds of contradictions broke out completely during the cultural revolution. It became the fuse, almost destroyed Beijing opera, and made Duan Xiaolou a coward and no longer love Juxian. It was also in the criticism of the Cultural Revolution that Duan Xiaolou saw that after slandering Cheng Dieyi, he threw the sword closely linked to their fate into the sea of fire. Juxian immediately got rid of from the red guards and rushed to pick up the sword. If the sword is regarded as the initial intention of Xiaolou and Dieyi performing Peking Opera, the metaphor here was: Xiaolou began to give up this initial intention, and Juxian was trying to keep it for him. Duan Xiaolou told the red guards that he did not love Juxian and wanted to draw a clear line with her. She finally understood that the man who staged a hero to save the beauty in the brothel was just a coward. The reason for Juxian's tragedy was that she always could not get rid of her status as a prostitute and live like a normal person. And her love to Duan Xiaolou was an important symbol to prove that she was a normal person. She could have the right to love a person, not like prostitutes who existed only to satisfy men's sexual desire, which is the most important part of a normal person's life. In the cultural revolution, in order to protect himself, Duan exposed Juxian's prostitute identity to the red guards, which not only meant that Duan did not love Juxian, but also that Juxian could not get rid of her prostitute identity. His heroism was just a play, and she would always be a prostitute and will never be a normal person. All this was an illusion.

After the fight, Juxian returned the sword to Dieyi. During the Anti-Japanese War, Duan Xiaolou was sent to prison because of the conflict with the traitors. Juxian promised that she would return to the brothel if Dieyi saved him. At that time, Juxian broke her promise, and now she came to fulfill her promise again. She returned the far-reaching sword to Dieyi, and then hanged herself, like the Concubine who died for the overlord. She is as arrogant as Cheng Dieyi. Cheng Dieyi is difficult to pull 
out the opera, and Juxian cannot escape her fate. She was born humble, but she wanted a better life just like other people. She saw all the heartless feelings in the world.

\section{TRAGEDY OF CHARACTERS- DUAN XIAOLOU}

Duan Xiaolou was a person who moved towards compromise step by step. He always stood up and showed that he was not afraid of anything. He swallowed a lot of suffering alone. When Duan Xiaolou was young and vigorous, he would always hit his head with a sharp tool to show that his bones were hard, but the hammer of life smashed his bones more and more, smashing them into dross and trampling them. Duan Xiaolou has two concubines, Dieyi in the play and Juxian outside the play. They all committed suicide like concubines $\mathrm{Yu}$. And he was also a fake overlord. He has no heroic spirit like Xiang $\mathrm{Yu}$, the overload in the Peking Opera Farewell my concubine, but only lived like a coward.

In the first half of the film, Duan Xiaolou was a very likable character. Whether in his childhood, adolescence, or youth, he gave people a feeling of courage and enthusiasm. To help Dieyi relieve the pain of practicing martial arts, he deliberately kicked off the brick at the foot of Dieyi, and he did not regret it even if he was beaten by his master. He did not pay any attention to the capitalist Yuan Shiqing, even though Yuan Shiqing was feared by everyone. When he was in the brothel, he was not afraid of dignitaries to helped Juxian out of the siege. Facing the provocation of Japanese, he dared to smash a teapot on the head of the traitor. He was arrested and jailed and nearly killed, but he was not afraid.

However, it was such a lofty and unyielding character who broke through the moral bottom line again and again and became servile in the second half of the film. At the end of the film, in the criticism of the red guards, he even betrayed his close relatives: Cheng Dieyi and Juxian, to protect himself, which made him become a tragic and hateful character.

As mentioned above, Juxian and Cheng Dieyi did not look as brave as Duan Xiaolou. Duan Xiaolou was not afraid of the Japanese army, while Cheng Dieyi went to play drama to the Japanese; Duan Xiaolou dared to rescue Juxian from the nobles, while Juxian only wants to live carefully.

Duan Xiaolou loved Cheng Dieyi and Ju Xian, Duan Xiaolou also loved his country, but his feelings are superficial. All the things he did, to some extent, were for the recognition of others and for the correct values of his society. He protected the Dieyi because the troupe paid attention to friendship. Stabbing Dieyi with a cigarette pole was also for the honor of the troupe, not just for Dieyi. Duan's sorrow stemmed from his drifting personality, which was typical of most people at the period. Since they drifted with the tide, their love, hate and hatred changed with the changed of the times. The values of the old society let Duan care about his younger martial brother Dieyi and let him love prostitute Juxian. But when the wheels of the new era crush the values of the old society, Duan also lost the courage to be a overlord and the courage to love Dieyi and Juxian.

If Juxian and Dieyi's "justice" and "injustice" were all due to their faith, Duan Xiaolou's courage and cowardice are derived from the same origin. He has never adhered to the world independently. Instead, he would become what the society has become. Great changes happened in the 1940s and 1950s in China. Before that, during the Anti-Japanese War, Duan Xiaolou has righteous values. But after that, social values blurred. In the conflict with the Kuomintang soldiers, Cheng Dieyi was arrested as a traitor, and Juxian miscarried in the process of protecting him. Duan Xiaolou fell into confusion in this new society.

In the Cultural Revolution, the confused Duan Xiaolou completely became a coward. The honest and brave Duan Xiaolou disappeared and was replaced by a traitor without a bottom line, because the Cultural Revolution launched an attack in the name of the people. In the face of the Japanese, Duan Xiaolou can resist all this from the standpoint of a dignified Chinese. $\mathrm{He}$ believed that his actions could be recognized by most people in society, which gave him courage. But at that particular time, it was the people who declared them guilty, declared them decadent feudal dross and declared them enemies of the people. Duan Xiaolou, an ordinary person, was knocked down.

Duan Xiaolou's degeneration was not all his fault, because he was a tragedy caused by that terrible era. In fact, there were many people like Duan Xiaolou at that time. Many patriots in China could fight the Japanese in the Anti-Japanese War and even directly participate in the battlefield, but they can not preserve their dignity during the cultural revolution. In the final analysis, one's courage against one group always comes from another group. The will of artists, writers, musicians, and many intellectuals were destroyed by the collective violence of the public, because they instinctively believed that the majority must be right. When people in the new era smash all the values of the old society, no one in the old society can survive well [5].

\section{TRAGEDY OF PEKING OPERA}

The year 1990 marks the 200th anniversary of the entry of Peking Opera into Beijing. And the film was also released in the 1990s to commemorate Peking Opera, which is the carrier of characters and events in the film. Also, the rise and fall of Peking Opera is an important content of the film. In the film, Cheng Dieyi, 
who was born for the play, was the embodiment of Beijing opera art. Cheng Dieyi's life track also reflects the development of Peking Opera in the 20th century.

\subsection{The origin and development of Peking Opera before the founding of the New China}

Since 1790, various types of opera classes in the South have successively entered Beijing. After about 120 years of development, Peking Opera has reached its peak level in the 1920s.

In the 1930s, the Japanese army occupied Beijing. Peking Opera had proved that the excellent culture would not be bound by national boundaries.

The victory of the Anti-Japanese war was a magnificent feat of the Chinese people. But it was also the beginning of the decline of Peking opera. In the theater of the 1940s, Kuomintang soldiers made loud noises, shone flashlights on the actors on the stage, and insulted Cheng Dieyi with dirty words. Cheng Dieyi was even arrested for being a traitor because he performed Peking Opera for the Japanese. Peking Opera slowly began to be disrespected.

\subsection{The conflict between Peking Opera and modern opera}

In the 1950s, the Communist Party won the war of liberation, established the Republic, and led the Chinese people to complete the great transformation from feudal society to socialist society, which was an unprecedented social revolution in Chinese history for thousands of years. Peking Opera, the product of feudal society, was naturally incompatible with this new society. Not only were the stories of Peking Opera related to figures including emperors, generals, talents, and beauties in feudal society, but also Peking Opera classes had formed a strict feudal hierarchical relationship. However, earth shaking changes had taken place in the new society. Many feudal lords and landlords had been sentenced to death in the Anti- Rebellion Movement. And the common people like farmers and workers had become the masters of country and the main role in Chinese politics. As the product of the new era, modern opera has emerged, and there had been great contradictions and conflicts with traditional Peking Opera.

At that time, modern drama was too much in pursuit of serving political propaganda, and as a new thing, it was not mature enough. With the founding of New China, socialist culture also began to infiltrate into Peking opera. Modern opera was the product of socialist culture, which wanted to prove that it was more advanced and superior to Peking opera. However, in the $1950 \mathrm{~s}$, the traditional values had been knocked down, and the new values had not been formed, which made modern drama had no unique aesthetics and connotation.

\subsection{Criticism of Peking opera during the Cultural Revolution}

The Cultural Revolution turned the 1960s into a terrible era. The contradiction between old and new cultures and values reached its peak. Many traditional Chinese buildings were demolished, many ancient Chinese books and documents were burned, and many Chinese intellectuals were persecuted. All those who were supported in the old society were destroyed during the cultural revolution, Peking Opera was no exception. At this time, Peking Opera has reached its lowest point, and people could not see its future at all.

\subsection{The historical impacts on the Peking Opera}

It is worth mentioning that there is a meaningful clip at the end of the film, as a member of the red guards in the cultural revolution, Xiaosi picked up the Peking Opera jewelry Yuan Shiqing gave Cheng Dieyi before and performed Peking Opera alone. The director implies here that even if Peking Opera was suppressed and criticized, the beauty in Peking opera art would never be eliminated. Instead, it would always exist in people's hearts. After all, whether people in the new era or in the old era, their pursuit of beauty is eternal.[6]

It is true that the strict feudal hierarchical order in Peking Opera classes would not be supported, and it was also incorrect for masters to beat apprentices. However, the master's care for the disciples was beyond doubt, and beating the disciples was also to make them train hard. Whether in the new era or the old era, hard work was the only way to success. Endure hardships and be capable of hard work, which was a good habit that still need to be inherited in the new society. Similarly, the artistic value of Peking Opera should not be ignored. Peking Opera should be reformed rather than eliminated. People should make the story of Peking Opera conform to the values of the new society and pay attention to and further explore the aesthetics and connotation of Peking Opera, bring forth the new through the old and discard the old ways of life in favor of the new. Therefore, Peking Opera can embody the spirit of the times and meet the people's demand for excellent culture.

\section{CONCLUSION}

There is internal logic among individual, cultural, and historical tragedies, which jointly construct the tragic aesthetics of Farewell My Concubine. Taking Peking opera as the main line, the three show a progressive relationship. Culture leads the development of people, and history leads the development of culture. Historical tragedies create cultural tragedies, and both historical tragedies and cultural tragedies create 
individual tragedies. As Schiller believes, the tragic fate of characters must be created by the environment. The result of tragedy lies in the individual. Historical tragedy and cultural tragedy are manifested through individual tragedy. Under the multiple perspectives of history, culture and individual, it shows the deep-seated tragic aesthetics [7].

\section{REFERENCES}

[1] Song Liran. An analysis of the emotion and fate tragedy of the film Farewell My Concubine [J] Anhui Literature (second half of the month),2009, (05):194

[2] Zhang Xiaohui \& Tong Huijie. Diagnosis of gender identity disorder -- views from DSM-4, CCMD-3 and ICD-10[J] Neurological diseases and mental health,2006(05)
[3] Ma Mingyi. Aesthetic analysis of Cheng Dieyi's character image in Farewell My concubine[J] Peony,2021(06)

[4] $\mathrm{Yu}$ Zhe. The triple tragedy of Cheng Dieyi in Farewell My Concubine[J] Masterpieces Review,2020, (02)

[5] Wang Shuping. The pursuit of ideal personality and order - the exploration into the theme of Farewell My Concubine[J] Journal of Suihua University, 2021,41(06)

[6] Liu Jingyun. On the polysemy of the film farewell my concubine $[\mathrm{J}] \mathrm{On}$ the polysemy of the film Farewell My Concubine, 2019,39(12):81-84

[7] Lei Fangfang. Tragic aesthetic analysis of Farewell My Concubine[J] Drama House 2021, (17), 12-13 